\title{
Phage Receptor Material in Lactobacillus casei
}

\author{
By TERUO YOKOKURA \\ Yakult Institute for Microbiological Research, \\ I796 Yaho, Kunitachi, Tokyo, Japan \\ (Received 29 September 1976; revised I 5 January 1977)
}

SUMMARY

In Lactobacillus casei S-I, D-galactosamine and L-rhamnose comprised a phage receptor for phage J-I. A mixture of D-galactosamine and L-rhamnose effectively inactivated phage $\mathrm{J}-\mathrm{I}$, and a J-I-resistant mutant strain, L. casei $\mathrm{S}-\mathrm{I} / \mathrm{J}-\mathrm{I}$, lacked D-galactosamine in its surface component. The phage-inactivating effects of D-galactosamine and L-rhamnose were strongly dependent on the concentration of each substance and on temperature.

It is suggested that the receptor for phage $\mathrm{J}$ - I involves both D-galactosamine in the cytoplasmic membrane and L-rhamnose in the wall of the host bacterium L. casei $\mathrm{S}-\mathrm{I}$, which lacks teichoic acid in its wall.

\section{INTRODUCTION}

In a previous paper (Yokokura, 197I), it was concluded that L-rhamnose in the wall Lactobacillus casei was one of the components of receptor material for phage J-I since L-rhamnose not only inhibited phage adsorption on to the wall but also desorbed from the wall phages which had been adsorbed to it. The effects of D-galactosamine on these phenomena have been studied.

\section{METHODS}

Bacteria and bacteriophage. The bacterial strain, Lactobacillus casei $\mathrm{S}-\mathrm{I}$, and the bacteriophage J-I were those previously reported (Yokokura, 197I). Lactobacillus casei $\mathrm{S}-\mathrm{I} / \mathrm{J}-\mathrm{I}$, which is a mutant strain resistant to phage $\mathrm{J}-\mathrm{I}$, was isolated from strain S-I as described by Chatterjee (1969) using $N$-methyl- $N^{\prime}$-nitro- $N$-nitrosoguanidine. The Y.P. broth and crude wall, purified wall and TCA (trichloroacetic acid)-soluble fraction were prepared as described previously (Yokokura, I97I). Phage J-I was purified as described by Yamamoto et al. (1970) using polyethylene glycol. It was inactivated with hexosamine and sugar as follows: a suspension of purified phage $\mathrm{J}-\mathrm{I}\left[0.05 \mathrm{ml}\right.$, $10^{9}$ plaque-forming units (p.f.u.) $\mathrm{ml}^{-1}$ ] was added to $5.0 \mathrm{ml} \mathrm{O} \cdot \mathrm{I} \mathrm{M}$-Tris/ $\mathrm{HCl}$ buffer $(\mathrm{pH} 7 \cdot 4$ ) containing various hexosamines and sugars, and the mixture was incubated at $37^{\circ} \mathrm{C}$. From this incubation mixture, samples were withdrawn at intervals and the number of active phages was assayed.

Chemical analyses. Quantitative analysis for sugars and sugar alcohols in the wall or TCA-soluble fraction was performed as described by Sweeley et al. (1963) with a GC-5A gas-liquid chromatograph (Shimadzu Seisakusho, Kyoto, Japan) equipped with a hydrogen flame ionization detector on a $3 \times 1000 \mathrm{~mm}$ glass column with $20 \%$ Silicone SE-52 on Celite 545 (Nihon Kuromato Kogyo Co., Tokyo, Japan). Amino acids and hexosamines were estimated with a KLA-3B amino acid autoanalyser (Hitachi, Tokyo, Japan) after hydrolysis as described by Ikawa \& Snell (1960). Hexosamines were also estimated by the method of Stewart-Tull (I 968). 
Table I. Chemical composition of L. casei $\mathrm{S}-\mathrm{I}$ and $\mathrm{S}-\mathrm{I} / \mathrm{J}-\mathrm{I}$ walls

Results are expressed as $\mu \mathrm{mol}$ (mg dry wt material) ${ }^{-1}$.

\begin{tabular}{lccc} 
Component & \multicolumn{2}{c}{ Strain S-I/J-I } \\
\cline { 2 - 4 } Rhamnose & \multicolumn{1}{c}{ Strain S-I } & $\begin{array}{c}\text { TCA-soluble fraction } \\
\text { from wall }\end{array}$ & Wall \\
Glucose & 0.58 & 2.92 & \\
Galactose & 0.70 & 1.97 & 0.90 \\
Glucosamine & 0.69 & $\mathrm{I} \cdot 79$ & - \\
Galactosamine & 0.09 & - & 0.70 \\
Muramic acid & 0.54 & - & - \\
Lysine & 0.29 & - & 0.66 \\
Aspartic acid & 0.19 & - & 0.44 \\
Glutamic acid & $0.3 \mathrm{I}$ & - & 0.20 \\
Alanine & 0.53 & - & 0.40 \\
&,- Indicates a value of less than $0.0 \mathrm{I}$. &
\end{tabular}

Electron microscopy. Phage J-I was treated with a mixture of hexosamine and sugar and dialysed against $0.1 \mathrm{M}$-ammonium acetate at $5{ }^{\circ} \mathrm{C}$ for $6 \mathrm{~h}$. The phages, which were negatively stained with phosphotungstic acid, were examined in a JEM-7A electron microscope (Japan Electron Optics Laboratory, Tokyo, Japan).

Preparation of antisera and antigens. Lactobacillus casei $\mathrm{S}-\mathrm{I}$ or S-I/J-1 was cultivated in Y.P. broth at $37^{\circ} \mathrm{C}$ for $18 \mathrm{~h}$. Cells were collected by centrifugation, washed with saline and suspended in saline. The cell suspension was injected into rabbits intravenously after it had been heated at $60^{\circ} \mathrm{C}$ for $30 \mathrm{~min}$. The TCA-soluble fraction was used as antigen in the test for two-dimensional precipitin reaction in gel (Ouchterlony, I967).

\section{RESULTS}

Composition of the walls of L. case $\mathrm{S} \mathrm{S}-\mathrm{I}$ and $\mathrm{S}-\mathrm{I} / \mathrm{J}-\mathrm{I}$

Chemical compositions of the wall and TCA-soluble fraction isolated from the wall are summarized in Table $\mathrm{I}$. The peptidoglycan of these strains was composed of muramic acid, glucosamine, lysine, aspartic acid, glutamic acid and alanine. Strains S-I and S-I/J-I differed in the composition of their wall polysaccharide, neither galactosamine nor galactose being detected in the latter strain. The number of amino acids decreased during purification of the walls. No glycerol or ribitol was detected.

\section{Inactivation of phage $\mathrm{J}-\mathrm{I}$}

The number of active phages was assayed after incubation with D-galactosamine, D-glucosamine or their $N$-acetyl derivatives $(0.5 \mathrm{M})$. Although D-galactosamine completely inactivated phage J-I and D-glucosamine slightly inactivated it, their $N$-acetyl derivatives had no effect (Fig. I). Neither $0.5 \mathrm{M}$-hydrochloric acid nor any of the amino acids found in the crude wall had any effect. The rate of phage inactivation by D-galactosamine in the presence of L-rhamnose was more than Ioo times faster than that with D-galactosamine alone (Fig. 2). L-Mannose and L-fucose slightly enhanced the inactivating effect of D-galactosamine. The longer the period of exposure to D-galactosamine, the more rapidly the phages were inactivated on subsequent addition of L-rhamnose (Fig. $3 a$ ). The period of exposure to 


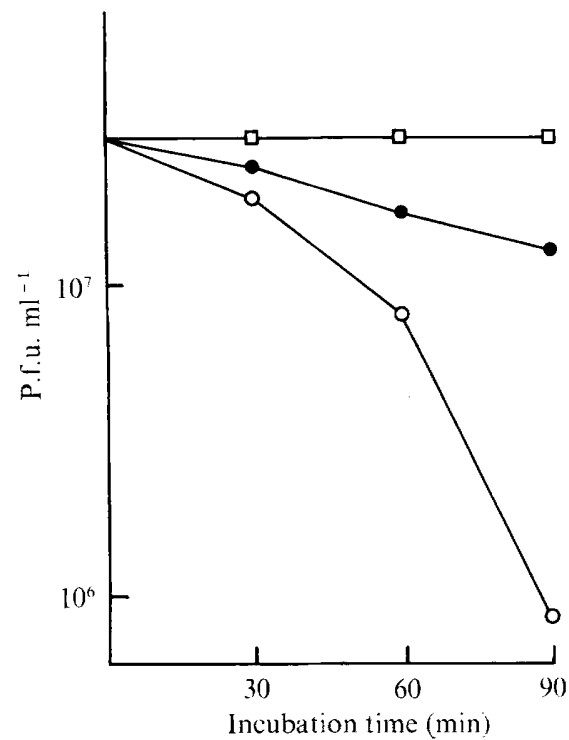

Fig. I

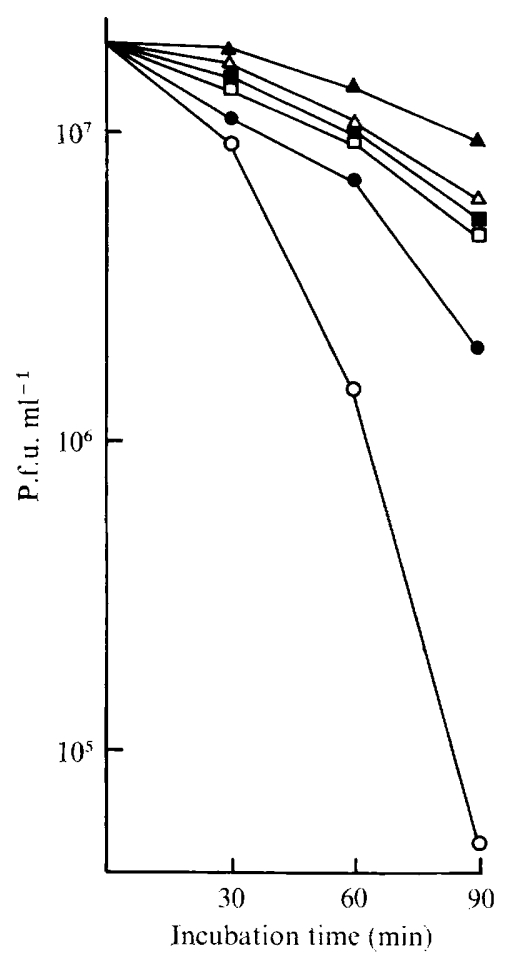

Fig. 2

Fig. I. Inactivation of phage $\mathrm{J}-\mathrm{I}$ with $0.5 \mathrm{M}$-hexosamine. Phage $\mathrm{J}-\mathrm{I}$ suspension ( $\mathrm{IO}^{9} \mathrm{p} . \mathrm{f} . \mathrm{u} . \mathrm{ml}^{-1}$, $0.05 \mathrm{ml}$ ) was incubated in $5.0 \mathrm{ml} 0.1 \mathrm{M}$-Tris $/ \mathrm{HCl}$ buffer $(\mathrm{pH} 7.4)$ containing D-galactosamine $(\mathrm{O})$, D-glucosamine (๑), or $N$-acetylhexosamine ( $N$-acetylgalactosamine or $N$-acetylglucosamine)" $(\square)$. Samples were withdrawn at intervals and the number of active phages was counted, after dilution, by the agar layer method.

Fig. 2. Inactivation of phage J-I with $0.2 \mathrm{M}$-D-galactosamine plus $0.2 \mathrm{M}$-sugar. $(O)$ L-Rhamnose; ( ) L-mannose; ( $\square$ ) L-fucose; ( $\mathbf{(})$ D-galactose; $(\triangle)$ D-mannose or D-glucose; (A) D-galactosamine alone. The mixture was incubated at $37^{\circ} \mathrm{C}$ and the number of active phages was assayed at $30 \mathrm{~min}$ intervals.

L-rhamnose, however, did not affect the rate of phage inactivation on addition of D-galactosamine (Fig. $3 b$ ). The survival rate of phage $\mathbf{J}$ - I was assayed after incubation with various concentrations of D-galactosamine and L-rhamnose for $90 \mathrm{~min}$. Although L-rhamnose $(0.5 \mathrm{M})$ did not inactivate phage $\mathrm{J}-\mathrm{I}$, it enhanced the inactivating effect of D-galactosamine at all concentrations tested (Table 2). The inactivating effect was observed at temperatures above $20^{\circ} \mathrm{C}$ when the concentrations of D-galactosamine and L-rhamnose were $0.2 \mathrm{M}$ (Table 3). Cooling (Fig. $4 a, b$ ) or dilution (Fig. $4 b$ ) of the mixture prevented inactivation.

The serological properties of $L$. case $i \mathrm{~S}-\mathrm{I} / \mathrm{J}-\mathrm{I}$ and its parent strain S-I were compared. Two precipitin bands, $a$ and $b$ (Fig. 5), were strain specific and $L$. casei group B specific, respectively (Shimohashi et al., 197I). Lactobacillus casei S-I/J-I lacked the latter band. When phage J-I was treated with D-galactosamine and L-rhamnose at $37^{\circ} \mathrm{C}$ for $90 \mathrm{~min}$, the shapes of the phages were normal but their heads appeared to be empty (Fig. 6). 


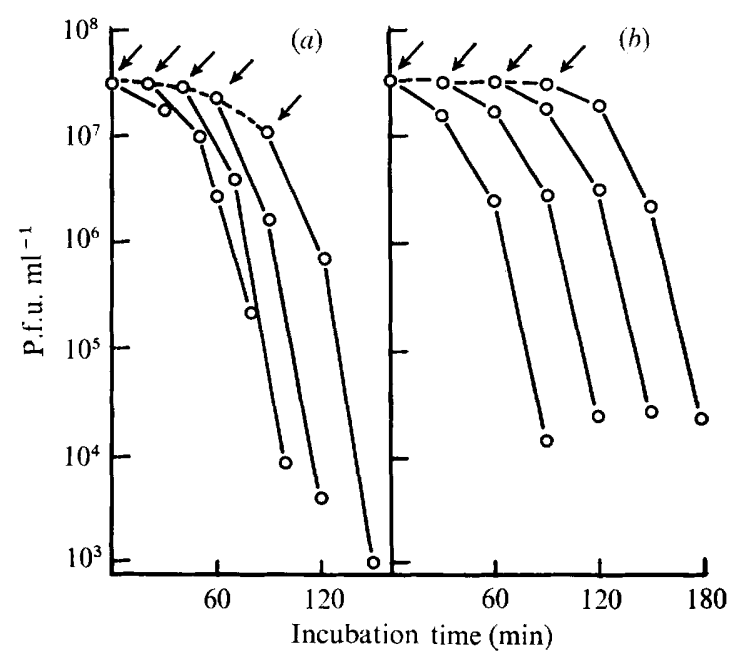

Fig. 3. Inactivation of phage J-I with D-galactosamine and L-rhamnose. Phage J-I was first incubated at $37^{\circ} \mathrm{C}$ with $(a) 0.2 \mathrm{M}$-D-galactosamine $\left(\mathrm{O}_{-}-\mathrm{O}\right)$ or $(b) 0.2 \mathrm{M}$-L-rhamnose $\left(\mathrm{O}_{-}--\bigcirc\right)$ and then (a) L-rhamnose or (b) D-galactosamine was added, as indicated by the arrows, to the incubation mixture to a final concentration of $0.2 \mathrm{M}$. After the addition, the number of active phages was assayed at $30 \mathrm{~min}$ intervals $(\mathrm{O}-\mathrm{O})$.

\section{Table 2. Effect of concentration of D-galactosamine and $\mathrm{L}$-rhamnose on phage $\mathrm{J}-\mathrm{I}$ inactivation}

Phage J-I was incubated with various concentrations of D-galactosamine and/or L-rhamnose in Tris/ $\mathrm{HCl}$ buffer $\left(\mathrm{pH} \mathrm{7.4)}\right.$ for $90 \mathrm{~min}$ at $37^{\circ} \mathrm{C}$. After incubation, the number of surviving phages was counted and the survival rate was calculated as follows:

\begin{tabular}{|c|c|c|}
\hline Survival rate $=$ & \multicolumn{2}{|c|}{$\frac{\text { p.f.u. of phage } \mathrm{J}-\mathrm{r} \mathrm{ml} \mathrm{ml}^{-1} \text { after incubation }}{\text { p.f.u. of phage } \mathrm{J}-\mathrm{I} \mathrm{ml}^{-1} \text { before incubation }}$} \\
\hline $\begin{array}{l}\text { D-Galactosamine } \\
\text { concn (M) }\end{array}$ & $\begin{array}{l}\text { L-Rhamnose } \\
\text { concn (M) }\end{array}$ & $10^{3} \times$ Survival rate \\
\hline 0 & 0 & 1000 \\
\hline$O \cdot I$ & 0 & 980 \\
\hline 0.2 & 0 & 800 \\
\hline 0.5 & 0 & 190 \\
\hline 0 & 0.5 & 1000 \\
\hline $0 . I$ & $0 . \mathrm{I}$ & 25 \\
\hline 0.1 & 0.2 & 23 \\
\hline $0 \cdot I$ & 0.5 & 17 \\
\hline 0.2 & $0 . I$ & 6.5 \\
\hline 0.2 & 0.2 & $2 \cdot 7$ \\
\hline 0.2 & 0.5 & $\mathrm{I} \cdot 2$ \\
\hline 0.5 & $0 . \mathrm{I}$ & 6.6 \\
\hline 0.5 & 0.2 & $\mathrm{I} \cdot 6$ \\
\hline 0.5 & 0.5 & 0.88 \\
\hline
\end{tabular}




\section{Table 3. Effect of temperature on phage J-I inactivation by D-galactosamine and L-rhamnose}

Phage J-I was incubated with $0.2 \mathrm{M}$-D-galactosamine and $0.2 \mathrm{M}$-L-rhamnose in Tris/HCl buffer (pH 7.4) for $90 \mathrm{~min}$ at various temperatures. After incubation, the survival rate was calculated as in Table 2.

$\begin{array}{cc}\text { Temperature }\left({ }^{\circ} \mathrm{C}\right) & 10^{3} \times \text { Survival rate } \\ 0 & 1000 \\ 10 & 980 \\ 20 & 810 \\ 25 & 2 \cdot 0 \\ 30 & 2 \cdot 4 \\ 35 & 2 \cdot 6 \\ 37 & 2 \cdot 7\end{array}$

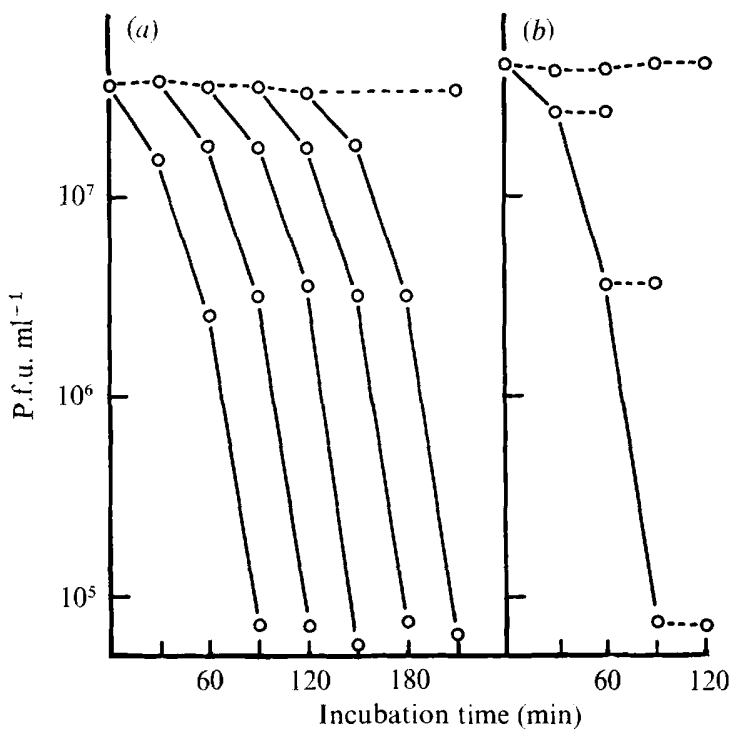

Fig. 4. Effect of temperature or concentration of D-galactosamine and L-rhamnose on inactivation of phage J-I. (a) Phage J- 1 was added to $0 . \mathrm{I} \mathrm{M-Tris} / \mathrm{HCl}$ buffer (pH 7.4) containing $0.2 \mathrm{M}-\mathrm{D}-$ galactosamine and $0.2 \mathrm{M}$-L-rhamnose chilled on ice and the number of active phages was measured at intervals $\left(\mathrm{O}_{---} \mathrm{O}\right)$. Samples were withdrawn at $30 \mathrm{~min}$ intervals, and assayed for active phages after further incubation at $37^{\circ} \mathrm{C}(\mathrm{O}-\mathrm{O})$.

(b) Phage J-I was incubated with $0.2 \mathrm{M}$-D-galactosamine and $0.2 \mathrm{M}-\mathrm{L}$-rhamnose at $37{ }^{\circ} \mathrm{C}(\mathrm{O}-\mathrm{O})$. The number of active phages was assayed after chilling in an ice bath or diluting 100 -fold with $0 . \mathrm{I} \mathrm{M}$-Tris/ $\mathrm{HCl}$ buffer $\left(\mathrm{pH}_{7} \cdot 4\right)$ at $37^{\circ} \mathrm{C}\left(\mathrm{O}_{--}-\mathrm{O}\right)$.

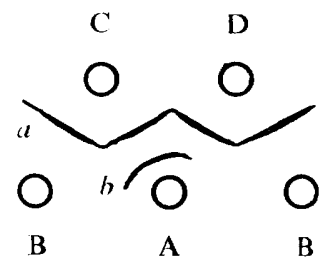

Fig. 5. Double immunodiffusion reaction between antisera and antigens of $L$. casei $\mathrm{S}-\mathrm{I}$ and $\mathrm{S}-\mathrm{I} / \mathrm{J}-\mathrm{I}$. A, Anti-S-I serum; B, anti-S-I/J-I serum; C, S-I antigen; D, S-I/J-I antigen. 

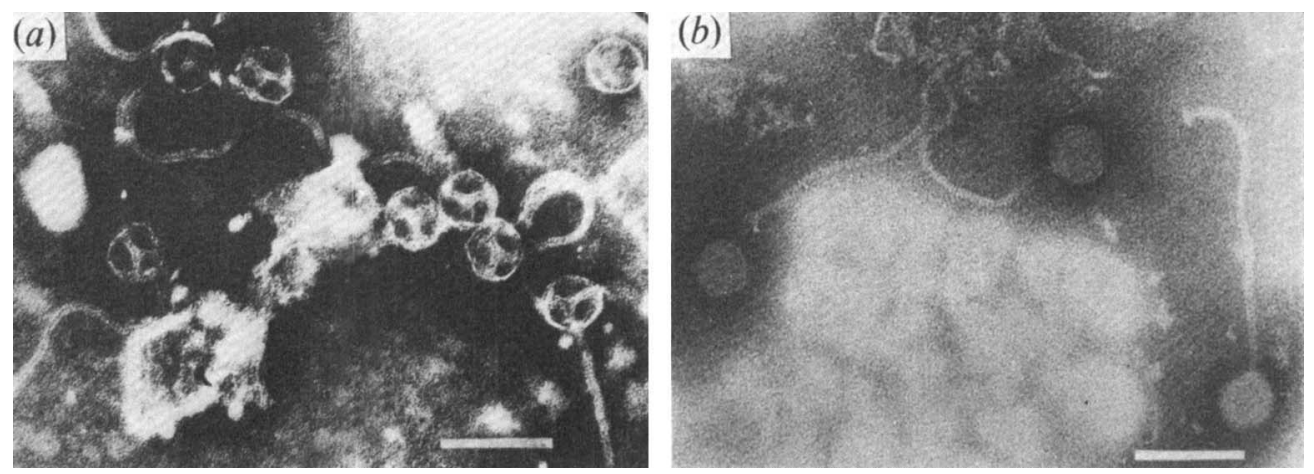

Fig. 6. Electron micrographs of phage $\mathrm{J}-1(a)$ treated with a mixture of $0.2 \mathrm{M}$-D-galactosamine and $0.2 \mathrm{M}-\mathrm{L}$-rhamnose for $90 \mathrm{~min}$ at $37^{\circ} \mathrm{C} ;(b)$ untreated control. Bar markers represent $0 . \mathrm{I} \mathrm{nm}$.

\section{DISCUSSION}

The chemical composition of $L$. case $i$ wall is well established (see, for example, Ikawa \& Snell, I960). It contains no teichoic acid and can be classified serologically into two groups, B and C (Knox, I963; Sharpe et al., I973). It has now been confirmed that L. casei S-I belongs to group $\mathrm{B}$ and that it has no teichoic acid in its wall.

Morse (1965) first suggested that teichoic acid is involved in the phage receptor and supporting evidence was first reported by Wolin, Archibald \& Baddiley (1966). Since then, the sugar moiety in wall teichoic acid has been implicated in the phage receptor in many Gram-positive bacteria such as Staphylococcus aureus (Coyette \& Ghuysen, 1968), Bacillus subtilis (Glaser, Ionesco \& Schaeffer, 1966) and Streptococcus faecium (Vidaver \& Brook, I966). Douglas \& Wolin (I97I) have also found that polysaccharide is essential for phage infection in Lactobacillus plantarum. Phage receptor material in L. case $i$ is interesting because this species does not contain teichoic acid in its wall.

Phage J-I was inactivated by the host's surface substances, D-galactosamine and L-rhamnose; the latter was the most effective sugar of those tested in enhancing the phage-inactivating effect of D-galactosamine. L-Mannose and L-fucose were also effective in the phage inactivation. The same trend was observed in the phage adsorption-inhibiting effects of sugars (Yokokura, I97I).

The group B specific antigen of $L$. case $i$ is determined by the L-rhamnosyl- $N$-acetylgalactosamine residue (Knox, I963). Therefore, the acquisition of resistance to phage J-I and deficiency of group-specific antigen in $L$. case $i$ S- I/J-I might result from the loss of D-galactosamine from the surface polysaccharide. Phages are inactivated by treatment with reagents such as sodium citrate which causes separation of head from tail and release of nucleic acid (Kuo et al., 197I). Such structural disorders were not observed in phage J-I inactivated with D-galactosamine and L-rhamnose, but the heads appeared to be empty. $\mathrm{D}$-Galactosamine and $\mathrm{L}$-rhamnose did not inactivate phages unrelated serologically to phage J-I, for example phages FYc and $\phi_{219}$ which are virulent to $L$. casei group $\mathrm{C}$ and L. plantarum, respectively (Sakurai et al., 1969). The inactivation of phage J-I with D-galactosamine and L-rhamnose is thus a specific biological effect. In coli phage $\mathrm{T}_{4}$, the process of adsorption is dependent on temperature but the process of inactivation is not (Stent, 1963). In phage $\mathrm{J}$-I, inactivation is dependent on temperature but adsorption is not.

The structure of phage $J$ - $I$ is simpler than those of T-even phages, having neither tailsheath nor tail-fibre. Therefore, infection by hage J-I may be more dependent on the host 
bacteria than are T-even phages. Since protease treatment removes the cytoplasmic membrane from crude wall (Sharpe et al., 1973) and the heads of phages adsorbed on to crude wall seem to be empty like those in Fig. 6(a), the irreversible adsorption of phage J-I on to crude wall described previously (Yokokura, 1971) may result from inactivation of the phage by a component of the cytoplasmic membrane in the crude wall. These findings suggest that phage $\mathrm{J}$-I needs both L-rhamnose in the wall and D-galactosamine in the cytoplasmic membrane for receptor material in $L$. casei $\mathrm{s}-1$.

\section{REFERENCES}

ChATterjee, A. N. (1969). Use of bacteriophage-resistant mutants to study the nature of the bacteriophage receptor site of Staphylococcus aureus. Journal of Bacteriology 98, 519-527.

COYETTE, J. \& GHUYSEN, J. M. (1968). Structure of the cell wall of Staphylococcus aureus, strain Copenhagen IX. Teichoic acid and phage adsorption. Biochemistry 7, 2385-2389.

Douglas, L. J. \& Woun, M. J. (1971). Cell wall polymers and phage lysis of Lactobacillus plantarum. Biochemistry ro, I55I-I555.

Glaser, L., Ionesco, H. \& SchaffFer, P. (I966). Teichoic acids as components of a specific phage receptor in Bacillus subtilis. Biochimica et biophysica acta 124, 415-417.

Ikawa, M. \& SNell, E. E. (1960). Cell wall composition of lactic acid bacteria. Journal of Biological Chemistry 235, 1376-1 382 .

KNox, K. W. (I963). Isolation of group specific products from Lactobacillus casei and L. casei var. rhamnosus. Journal of General Microbiology 31, 59-72.

Kuo, T. T., Chow, T. W., LIN, Y. T., YANG, C. W. \& LI, H. W. (I97I). Specific dissociation of phage Xp I 2 by sodium citrate. Journal of General Virology Io, I 99-202.

MorSE, S. I. (I965). Biological attributes of staphylococcal cell walls. Annals of the New York Academy of Sciences $128,191-213$.

OUCHTERLONY, O. (1967). Immunodiffusion and immunoelectrophoresis. In Handbook of Experimental Immunology, pp. 655-706. Edited by D. M. Weir. Oxford and Edinburgh: Blackwell Scientific Publications.

Sakurai, T., Takahashi, T., Kamiyama, K. \& Arai, H. (1969). Isolation of bacteriophages parasitic on Lactobacillus case $i$ and $L$. plantarum and their several properties. Virus 19, 3I I-324.

Sharpe, M. E., Brock, J. H., Knox, K. W. \& Wicken, A. J. (1973). Glycerol teichoic acid as a common antigenic factor in lactobacilli and some other Gram-positive organisms. Journal of General Microbiology 74, I I9-I 26.

Shimohashi, H., Shimizu, A., IIsaka, H. \& Arai, H. (1971). Studies on the type and group specific antigens in Lactobacillus casei group B. Japanese Journal of Bacteriology 26, $172-173$.

STENT, G. S. (1963). In Molecular Biology of Bacterial Viruses, pp. 88-1 15. San Francisco \& London: W. H. Freeman.

STEWART-TUlL, D. E. S. (1968). Determination of amino sugars in mixtures containing glucosamine, galactosamine, and muramic acid. Biochemical Journal rog, I3-I 8.

Sweeley, C. C., Bentley, R., Makita, M. \& Wells, W. W. (1963). Gas-liquid chromatography of trimethylsilyl derivatives of sugars and related substances. Journal of the American Chemical Society 85, 2497-2507.

Vidaver, A. K. \& Brock, T. D. (I966). Purification and properties of a bacteriophage receptor material from Streptococcus faecium. Biochimica et biophysica acta $\mathbf{r 2 r}, 298-314$.

Wolin, M. J., Archibald, A. R. \& Baddiley, J. (I966). Changes in wall teichoic acid resulting from mutations of Staphylococcus aureus. Nature, London 209, 484-486.

Yamamoto, K. R., Alberts, B. M., Benzinger, R., Lawhorne, L. \& Treiber, G. (1970). Rapid bacteriophage sedimentation in the presence of polyethylene glycol and its application to large-scale virus purification. Virology 40, 734-744.

YококURA, T. (197I). Phage receptor material in Lactobacillus casei cell wall. I. Effect of L-rhamnose on phage adsorption to the cell wall. Japanese Journal of Microbiology 15, 457-463. 